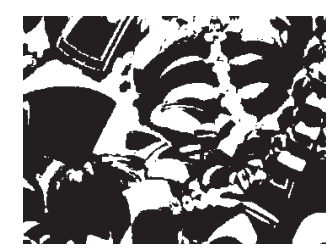

\title{
BUDGET TRANSPARENCY OF LOCAL GOVERNMENTS: THE POLITICAL ECONOMY OF CITY AND MUNICIPALITY BUDGETS IN CROATIA
}

Katarina OTT

Institute of Public Finance, Zagreb

Velibor MAČKIĆ

Faculty of Economics and Business, Zagreb

Mihaela BRONIĆ

Institute of Public Finance, Zagreb

UDK: 352.072.8(497.5)"2015/2016"

Izvorni znanstveni rad

Primlieno: 16. 7. 2017.

This paper investigates the budget transparency of Croatian local governments, i.e., the relationship between the open local budget index (OLBI) and a set of economic, political and socio-cultural variables. It uses a unique panel database of all 128 cities and 428 municipalities in 2015 and 2016 . To examine the differences among the samples and years and to determine whether the different samples have different driving forces, a regression analysis based on a Poisson distribution is used. In the total (cities and municipalities) and city samples, average income per capita (p.c.) is the most important determinant of the OLBI, which confirms Ferejohn's principal-agent model. At the municipality level, the findings indicate that political variables (ideology and political competition) are the factors that play the most important role, which is in line with the principal-agent and legitimacy theories. Findings point out to the necessity of reconsidering the number of local governments, particularly smaller ones lacking the capacity for maintaining basic budget transparency standards and to motivate citizens to demand and local governments to offer more budget transparency.

Keywords: budget transparency, local government, Croatia, political economy 
Budget transparency (BT) is recognized as an important feature of fiscal policy. It allows citizens to obtain budget information and contribute to the more efficient collection of public funds and supply of public goods and services, thereby increasing governments' accountability and citizens' trust and reducing opportunities for corruption (Alt \& Lowry, 2010; Hameed, 2005; Khagram, Fung, \& de Renzio, 2013; Kopits \& Craig, 1998; Piotrowski \& van Ryzin, 2007).

In this paper, local governments' (LGs') BT is defined as the ability for citizens to obtain online information about LGs' budgets that is complete, accurate, timely and presented in an understandable form. Budget information available on LGs' official websites is analysed because Internet reporting is fast, with low cost, wide reach and flexible formats (Debreceny, Gray, \& Rahman, 2002); consequently, it has been increasingly used in addition to paper-based budget reporting.

The Croatian government is committed to promoting both national and local government BT, as demonstrated by signing the Open Government Partnership initiative and the Ministry of Finance (MoF) issuing a recommendation to all LGs to annually publish five key local budget documents (budget proposal, enacted budget, citizens' budget, mid-year and end-year reports) on their official websites (Open Government Partnership, 2012). This recommendation was reiterated in several other acts and instructions of the MoF, but sanctions for not publishing these local budget documents were never introduced.

The open local budget index (OLBI) used in this work measures only the number of key local budget documents that each LG has annually timely published on its official website (Ott, Bronić, \& Petrušić, 2015; Ott, Bronić, Petrušić, \& Stanić, 2016). The yearly OLBI for each LG ranges from 0 to 5 (zero if it has not published any document, and five if it has published all five). The OLBI is available for all 576 Croatian LGs for two years. This already-constructed OLBI is used as a source of secondary data that can also be used by other researchers for their own samples; thus, its construction is not a focus of this paper. This measure and the approach taken in this paper can be generalized beyond Croatia, enabling other researchers to conduct similar work in other contexts.

The levels of LGs' OLBIs vary widely (Ott et al., 2015; Ott et al., 2016), and despite improvements in the OLBI's overall average level (from 1.75 in 2015 to 2.35 in 2016 for all LGs), it is still far from satisfactory. In 2016, on average, the most transparent were counties (4.3), whereas cities were less transparent (3.05), and municipalities were the least transparent (2.04).

The aim of this study is to explain such differences. Accordingly, two main research goals were established: (i) to 
DRUŠ. ISTRAŽ. ZAGREB GOD. 27 (2018), BR. 4 STR. 629-647

OTT, K., MAČKIĆ, V., BRONIC, M.: BUDGET... empirically identify the variables influencing the level of the OLBI for the total 'population' (cities + municipalities) and at two different samples and (ii) to identify and measure the differences among various samples and/or years. Based on a literature review and the researchers' own reasoning, a selected set of economic, political and socio-cultural determinants of BT on the municipality and city levels are examined. This paper does not address counties because that sample and the variation in their OLBI values are too small.

Since "the problems related to transparency are more frequent at local level, as local politicians are usually more discrete when it comes to taking decisions" (Araujo \& Tejedo-Romero, 2015, p. 2), and since researchers have not been able to provide consistent conclusions due to heterogeneous results regarding LG BT determinants (Alcaide Muñoz, Rodríguez Bolívar, \& López Hernández, 2017), this paper aims to clarify the previously identified determinants. It can be distinguished from the previous literature because it (i) uses a novel methodology (Poisson distribution), (ii) uses a rather large sample of 556 LGs in a fiscally centralized, post-socialist country, and (iii) except for Laswad, Fisher, and Oyelere (2005) it is the only research that looks at only whether LGs are timely publishing budgetary documents without checking the quality of data. Citizens of fiscally centralized, post-socialist countries probably care less about BT, because LGs themselves provide fewer public goods compared to the ones in fiscally decentralized countries. Furthermore, despite the alarming public debt and an unstable political situation, citizens seem to be neglecting their role in the budgetary process. In the "spirit of socialism", they regard public money as both "everybody's and nobody's" (Ott \& Bronić, 2015). Thus, without the sense of ownership, there is no incentive for citizens to actively participate in the budget process, which provides extensive manoeuvring space for opportunistic behaviour and rent-seeking activities for incumbents. This is tied to the previously established opportunistic behaviour of incumbents in LGs' election cycles (Mačkić, 2014; Vuković, 2017). This paper is also an attempt to improve practices which help citizens to participate in LGs' public finances.

The next sections provide the theoretical framework, a literature review, the data and methodology, the empirical results and the conclusions.

\section{THEORETICAL FRAMEWORK OF BUDGET TRANSPARENCY}

From the political economy perspective, BT is ultimately a question of incumbents' credibility, which depends on institutions and incentives. In Croatia, BT represents a credible commitment of a local incumbent within a given national institutional framework (Budget Act (2012), the Act on the Right 
DRUŠ. ISTRAŽ. ZAGREB GOD. 27 (2018), BR. 4, STR. 629-647

OTT, K., MAČKIĆ, V., BRONIĆ, M. BUDGET... of Access to Information (2013), and the MoF's recommendation with regard to issuing five key local budget documents) and incentives that arise from the Institute of Public Finance's (IPF) yearly ratings of LGs (Ott et al., 2015; Ott et al., 2016). The list can be further expanded with economic fundamentals, demographic information and the ideological stance of the incumbent (Alt, 2002).

Besley (2006) summarizes the literature on the political economy of public finance to median voter models and conflict of interest models (governors vs the governed). The latter recognize the limited ability to restrain the power of non-benevolent incumbents. One way to improve resource allocation is through increased transparency and accountability. The principal-agent model highlights that elections play a limited role in restraining incumbents' behaviour and/or in selecting a "good" politician. However, more disclosure can weaken the information asymmetry and decrease such problems for citizens (Jensen \& Meckling, 1976). Therefore, the principal-agent theory links more disclosure of budget information with better public-sector governance (Benito \& Bastida, 2009).

Two formal principal-agent models have been developed within the political economy literature regarding transparency, policy choices, and incumbent accountability. In Ferejohn's (1999) model, transparency is endogenous, i.e., the incumbent (agent) chooses how to make evident his actions to the voters (principal). Since it assumes that the incumbent is compensated by rents that are proportional to the scale of government, the result is straightforward. Agents have incentives to choose above zero transparency, leading to larger budgets and thus more rents compared to a situation in which most of their actions remain hidden from the principal. It also assumes that the principal uses so-called action monitoring when evaluating agents.

In Besley's (2006) model, bad and good agents decide on tax policy issues in more or less transparent situations. The former appropriates rents and thus maximizes private gains; the latter maximizes the social welfare. Depending on the equilibrium of a two-period model (pooled, separate and "hybrid"), various levels of public goods and rent extraction are recorded. The model yields discipline and selection which are at the heart of the agency problem and arise due to increased transparency. Higher transparency reduces extraction of rents; whereas selection allows voters to throw bad incumbents out of office.

The neo-institutional theory argues that organizations respond to external pressures (laws or public opinion), adopting legitimate and socially acceptable structures and practices, 
DRUŠ. ISTRAŽ. ZAGREB GOD. 27 (2018), BR. 4 STR. 629-647

OTT, K., MAČKIĆ, V., BRONIC, M.: BUDGET.. resulting in increasingly homogenous practices and structures (DiMaggio \& Powell, 1991; Rodríguez Bolívar, Alcaide Muñoz, \& López Hernández, 2013). Information disclosure becomes a symbol of trust and modernity to project an image of good governance and transparency (Rodríguez Bolívar et al., 2013).

Similarly, the legitimacy theory argues that if their legitimacy is threatened, organizations will disclose information to promote organizational legitimacy (Deegan, 2002; Patten, 1992). Consequently, increased BT can also lead to increased legitimacy of representative decision-making (Araujo \& Tejedo-Romero, 2016).

Within the public choice theory and based on the premise of a low citizen involvement, in the case of Croatia, the role of incumbents could be the most important factor (Lowi, 1972; Cullis \& Jones, 1997; McLean, 1997; Roemer, 2001). This paper assumes that incumbents carry at least some responsibility for the underperforming OLBIs in Croatia. With respect to Ferejohn's model, due to their on average smaller budgets and thus lower rent extractions, municipalities should exhibit lower OLBIs. Richer LG, mostly cities, should pay more attention to BT.

Additionally, it seems that the annual efforts of the IPF in making the OLBI results publicly visible by rewarding the most transparent LGs affects the incumbents' attitudes and increases OLBI results, i.e., neo-institutional theory provides a valid explanation with respect to increases in the average values of OLBI.

\section{LITERATURE REVIEW AND HYPOTHESES}

According to Pérez, Bolívar, and Hernández (2008), the incentives for disclosure of public financial information can be political (e.g., political competition, political culture), social (e.g., socio-economic level, population size), institutional/administrative (e.g., size of the government, staff characteristics) and economic or financial (e.g., debt or the cost of debt).

This investigation focuses on articles related to local budget/fiscal transparency, particularly those related to online BT. Table 1 presents selected works addressing the determinants of online BT and similar transparency indexes on the regional/ local government level.

One can conclude that first, there is both national and regional/local-level BT research, but mostly focusing on developed countries, rarely on post-socialist countries. Second, regional/local BT research focuses mostly on fiscally decentralized countries (e.g., the United States and Spain), in most cases ignoring fiscally centralized countries. Third, although there 
(1) TABLE 1

Selected studies analysing (online) BT and similar transparency indexes are still no clearly identified determinants of LGs' BT, some variables have emerged as potentially more probable: GDP/ income p.c. (depending on the national or regional level), political ideology, political competition, population, debt and the cost of debt.

\begin{tabular}{|c|c|c|c|c|}
\hline \multirow[b]{2}{*}{ Authors } & \multirow[b]{2}{*}{ Variable } & \multirow[b]{2}{*}{ Object of research } & \multicolumn{2}{|c|}{ Relationship with the dependent variable } \\
\hline & & & Positive & Negative \\
\hline $\begin{array}{l}\text { Giroux \& Mc- } \\
\text { Lelland (2003) }\end{array}$ & Disclosure index & $\begin{array}{l}\text { US cities over 100,000 } \\
\text { inhabitants }\end{array}$ & $\begin{array}{l}\text { Council-Manager cities } \\
\text { maintained superiority } \\
\text { over Mayor-Council cities }\end{array}$ & \\
\hline $\begin{array}{l}\text { Laswad, Fisher, } \\
\& \text { Oyelere (2005) }\end{array}$ & $\begin{array}{l}\text { Voluntary Internet } \\
\text { financial reporting }\end{array}$ & 86 LGs, New Zealand & $\begin{array}{l}\text { Financial leverage (long- } \\
\text {-term liabilities/total assets); } \\
\text { own revenue p.c.; press visibi- } \\
\text { lity; type of council (larger } \\
\text { councils perform better) }\end{array}$ & \\
\hline $\begin{array}{l}\text { Styles \& Ten- } \\
\text { nyson (2007) }\end{array}$ & $\begin{array}{l}\text { Comprehensive an- } \\
\text { nual financial reports }\end{array}$ & 300 US municipalities & $\begin{array}{l}\text { Population; income p.c.; } \\
\text { debt levels; municipalities' } \\
\text { financial position }\end{array}$ & \\
\hline $\begin{array}{l}\text { Pérez, Bolivar, \& } \\
\text { Hernandez (2008) }\end{array}$ & Disclosure index & $\begin{array}{l}\text { Sample of Spanish } \\
\text { municipalities }\end{array}$ & Debt costs; Internet access & \\
\hline $\begin{array}{l}\text { Serrano-Cinca, } \\
\text { Rueda-Tomás, \& } \\
\text { Portillo-Tarra- } \\
\text { gona (2009) }\end{array}$ & $\begin{array}{l}\text { Voluntary online } \\
\text { financial reporting } \\
\text { (e-disclosure) }\end{array}$ & $\begin{array}{l}92 \text { provincial capitals } \\
\text { and municipalities } \\
\text { with over } 70,000 \text { in- } \\
\text { habitants, Spain }\end{array}$ & $\begin{array}{l}\text { Income p.c.; population; } \\
\text { political will (councils' ex- } \\
\text { perience with e-democracy) }\end{array}$ & \\
\hline $\begin{array}{l}\text { García \& } \\
\text { García (2008) }\end{array}$ & $\begin{array}{l}\text { Voluntary financial } \\
\text { disclosures on the } \\
\text { Internet }\end{array}$ & $\begin{array}{l}334 \text { Spanish munici- } \\
\text { palities }\end{array}$ & $\begin{array}{l}\text { Population; capital invest- } \\
\text { ment; political competition }\end{array}$ & Press visibility \\
\hline $\begin{array}{l}\text { Gallego-Álvarez, } \\
\text { Rodríguez-Do- } \\
\text { mínguez, \& Gar- } \\
\text { cía-Sánchez (2010) }\end{array}$ & $\begin{array}{l}\text { Digital governance } \\
\text { index }\end{array}$ & $\begin{array}{l}81 \text { of the largest } \\
\text { municipalities from } \\
81 \text { countries }\end{array}$ & $\begin{array}{l}\text { Institutional capacity (ad- } \\
\text { ministrative and financial } \\
\text { capacity - measured by } \\
\text { budgetary expenses p.c.); } \\
\text { population }\end{array}$ & \\
\hline $\begin{array}{l}\text { Guillamón, } \\
\text { Bastida, \& } \\
\text { Benito (2011) }\end{array}$ & $\begin{array}{l}\text { Financial } \\
\text { transparency } \\
\text { index }\end{array}$ & $\begin{array}{l}100 \text { largest Spanish } \\
\text { municipalities }\end{array}$ & $\begin{array}{l}\text { Taxes and transfers p.c.; } \\
\text { population; left-wing par- } \\
\text { ties are more transparent } \\
\text { than right-wing parties }\end{array}$ & \\
\hline Ma \& Wu (2011) & FT index & 31 provinces, China & $\begin{array}{l}\text { Institutional capacity; } \\
\text { economic openness; } \\
\text { marketization; local } \\
\text { leaders' attributes } \\
\text { (e.g., tenure in office) }\end{array}$ & \\
\hline $\begin{array}{l}\text { Esteller-Moré } \\
\& \text { Otero (2012) }\end{array}$ & FT & $\begin{array}{l}691 \text { Catalan } \\
\text { municipalities }\end{array}$ & $\begin{array}{l}\text { Political competition; } \\
\text { decentralization }\end{array}$ & \\
\hline $\begin{array}{l}\text { Caamaño-Alegre } \\
\text { et al. (2013) }\end{array}$ & $\mathrm{BT}$ & $\begin{array}{l}33 \text { Galician } \\
\text { municipalities }\end{array}$ & $\begin{array}{l}\text { Leftist incumbent; } \\
\text { electoral competition; } \\
\text { budget balance }\end{array}$ & $\begin{array}{l}\text { Unemployment; } \\
\text { coalition; } \\
\text { budget size }\end{array}$ \\
\hline
\end{tabular}

(continued) 


\begin{tabular}{|c|c|c|c|c|}
\hline \multirow[b]{2}{*}{ Authors } & \multirow[b]{2}{*}{ Variable } & \multirow[b]{2}{*}{ Object of research } & \multicolumn{2}{|c|}{ Relationship with the dependent variable } \\
\hline & & & Positive & Negative \\
\hline Sol (2013) & Transparency index & $\begin{array}{l}\text { Sample of Spanish } \\
\text { municipalities }\end{array}$ & $\begin{array}{l}\text { Population; } \\
\text { left-wing mayors }\end{array}$ & $\begin{array}{l}\text { Provincial capitals; } \\
\text { tourist cities; } \\
\text { mayors with } \\
\text { absolute majority }\end{array}$ \\
\hline $\begin{array}{l}\text { García-Tabuyo, } \\
\text { Sáez-Martin, \& } \\
\text { Caba-Pérez (2016) }\end{array}$ & $\begin{array}{l}\text { Index of voluntary } \\
\text { disclosures }\end{array}$ & $\begin{array}{l}40 \text { largest municipali- } \\
\text { ties selected in each of } \\
\text { five Central American } \\
\text { countries }\end{array}$ & $\begin{array}{l}\text { Political commitment } \\
\text { (voter turnout); legal } \\
\text { disclosure requirements } \\
\text { (information legally } \\
\text { required to be disclosed) }\end{array}$ & $\begin{array}{l}\text { Technology (Inter- } \\
\text { net penetration); } \\
\text { corruption }\end{array}$ \\
\hline $\begin{array}{l}\text { Alcaide Muñoz, } \\
\text { Rodríguez Bolí- } \\
\text { var, \& López Her- } \\
\text { nández (2017) }\end{array}$ & $\begin{array}{l}\text { Disclosure of online } \\
\text { public financial } \\
\text { information }\end{array}$ & $\begin{array}{l}\text { Empirical results of } \\
51 \text { articles }\end{array}$ & $\begin{array}{l}\text { Financial condition (debt); } \\
\text { political competition in- } \\
\text { dexes; size of the LG } \\
\text { (number of inhabitants, } \\
\text { total revenues, total assets, } \\
\text { number of public emplo- } \\
\text { yees); LGs' income level }\end{array}$ & \\
\hline $\begin{array}{l}\text { Araujo \& } \\
\text { Tejedo-Ro- } \\
\text { mero (2016) }\end{array}$ & Transparency index & $\begin{array}{l}\text { 8,112 Spanish } \\
\text { municipalities }\end{array}$ & Political competition & $\begin{array}{l}\text { Electoral turnout; } \\
\text { political ideology } \\
\text { (leftist incumbent) }\end{array}$ \\
\hline
\end{tabular}

Based on the literature review and the researchers' own reasoning, four hypotheses are proposed.

(1) Residents' p.c. income has a statistically significant and positive effect on the OLBI.

Residents with higher incomes expect more public services, demand more information (Giroux \& McLelland, 2003; Piotrowski \& van Ryzin, 2007) and have more access to and experience in using the Internet (Styles \& Tennyson, 2007). Ferejohn (1999) also argues that agents' discipline shows a positive correlation with the size of the budget under the threat of being replaced in elections if $\mathrm{s} / \mathrm{he}$ acts otherwise.

(2) The political ideology of the governing party has a statistically significant influence on the OLBI.

This study expects a negative and significant effect for right-wing parties and a positive and significant effect for left-wing parties. Due to their bias towards expanding public services, left-wing parties/incumbents face greater transparency requirements and are more transparent (Caamaño-Alegre, Lago-Peñas, Reyes-Santias, \& Santiago-Boubeta, 2013; Guillamón, Bastida, \& Benito, 2011). Ferejohn's (1999) principal-agent model explains this through incumbents' rent extraction which leads to larger budgets and above zero transparency. Sol (2013) also argues that left-wing governments are more sensitive to the provision of transparency than right-wing governments.

(3) Population has a statistically significant and positive effect on the OLBI. 
DRUŠ. ISTRAŽ. ZAGREB GOD. 27 (2018), BR. 4, STR. 629-647

OTT, K., MAČKIĆ, V., BRONIĆ, M.: BUDGET...
(1) TABLE 2

Description of the variables and data sources
The pressure to be transparent is greater in larger than in smaller cities/municipalities (Serrano-Cinca, Rueda-Tomás, \& Portillo-Tarragona, 2009) because the larger ones provide services to a higher population, resulting in greater demand and the need for more disclosure of information (Styles \& Tennyson, 2007). Also, LGs with more residents must respond to greater external pressures and thus are more likely to adopt BT practices that are considered legitimate and socially acceptable (neo-institutional theory). Furthermore, larger cities generally have higher budgets for information technology (IT) services and can have better websites. With larger administrative staff, larger LGs can more easily meet transparency requirements (Caamaño-Alegre et al., 2013).

(4) Political competition variables have a statistically significant and positive effect on the OLBI.

This study expects two political competition variables incumbent faced more than one competitor in elections and incumbent was backed by more than one party - to be positively associated with BT. In the latter case, according to McLean (1997), a higher number of parties in a coalition does not mean low competition overall; it is just transferred from the public sphere within the coalition itself. With little political competition, politicians have high expectations of remaining in power, tend to be less transparent and to ignore their electoral promises (Araujo \& Tejedo-Romero, 2016; Gandía \& Archidona, 2008; García \& García, 2008). Legitimacy theory argues that greater political competition leads to the voluntary demonstration of incumbents' efficient management (Alcaide Muñoz et al., 2017). Agency theory states that higher political competition is an incentive for the incumbents to perform well (to respond to the interests of citizens - Araujo \& Tejedo-Romero, 2016; Pérez et al., 2014).

The descriptions of the variables and data sources used in the empirical part of the paper are presented in Table 2.

\begin{tabular}{|c|c|c|}
\hline Variable & Description & Data Source \\
\hline ln_pop & $\begin{array}{l}\text { Logarithm of the number of inhabitants according } \\
\text { to the } 2011 \text { Census (in 100,000) }\end{array}$ & Croatian Bureau of Statistics (2016) \\
\hline In_income_p.c. & $\begin{array}{l}\text { Logarithm of the average p.c. residents' income } \\
\text { (in 10,000 HRK) }\end{array}$ & $\begin{array}{l}\text { Ministry of Regional Development } \\
\text { and EU Funds (2016) }\end{array}$ \\
\hline ln_tc p.c. & Logarithm of the total LG expenditures p.c. & Ministry of Finance (2016) \\
\hline$e d u \_l$ & $\begin{array}{l}\text { Dummy variable that takes the value of } 1 \text { if the mayor/ } \\
\text { municipality head has secondary school diploma }\end{array}$ & $\begin{array}{l}\text { Committee in Charge of Monitor- } \\
\text { ing Conflicts of Interest (2016) }\end{array}$ \\
\hline ideo_r & $\begin{array}{l}\text { Dummy variable that takes the value of } 1 \text { if the incumbent is } \\
\text { a member of Croatian Democratic Union (HDZ) or a coalition } \\
\text { in which the HDZ participates, i.e., a right-wing politician }\end{array}$ & State Electoral Commission (2016) \\
\hline NoCand_2013 & $\begin{array}{l}\text { Discrete and positive number indicating the number of } \\
\text { candidates for the mayor/municipality head }\end{array}$ & State Electoral Commission (2016) \\
\hline Coal_2013 & $\begin{array}{l}\text { Dummy variable that takes the value of } 1 \text { if the incumbent } \\
\text { was backed by more than one party in the elections }\end{array}$ & State Electoral Commission (2016) \\
\hline
\end{tabular}




\section{DATA AND METHODOLOGY}

Based on the stochastic process theory, the natural model for count data such as the dependent variable in this study (OLBI) is a Poisson distribution. This applies regardless of whether the dependent variable exhibits equidispersion (the variance equals the mean) or overdispersion (the variance is greater than the mean). ${ }^{1}$ Table 3 presents the descriptive statistics for

(4) TABLE 3

OLBI the dependent variable. The data indicate that in the 2015 total summary statistics and municipalities samples there is overdispersion, whereas in all other samples the variance is slightly less than the mean.

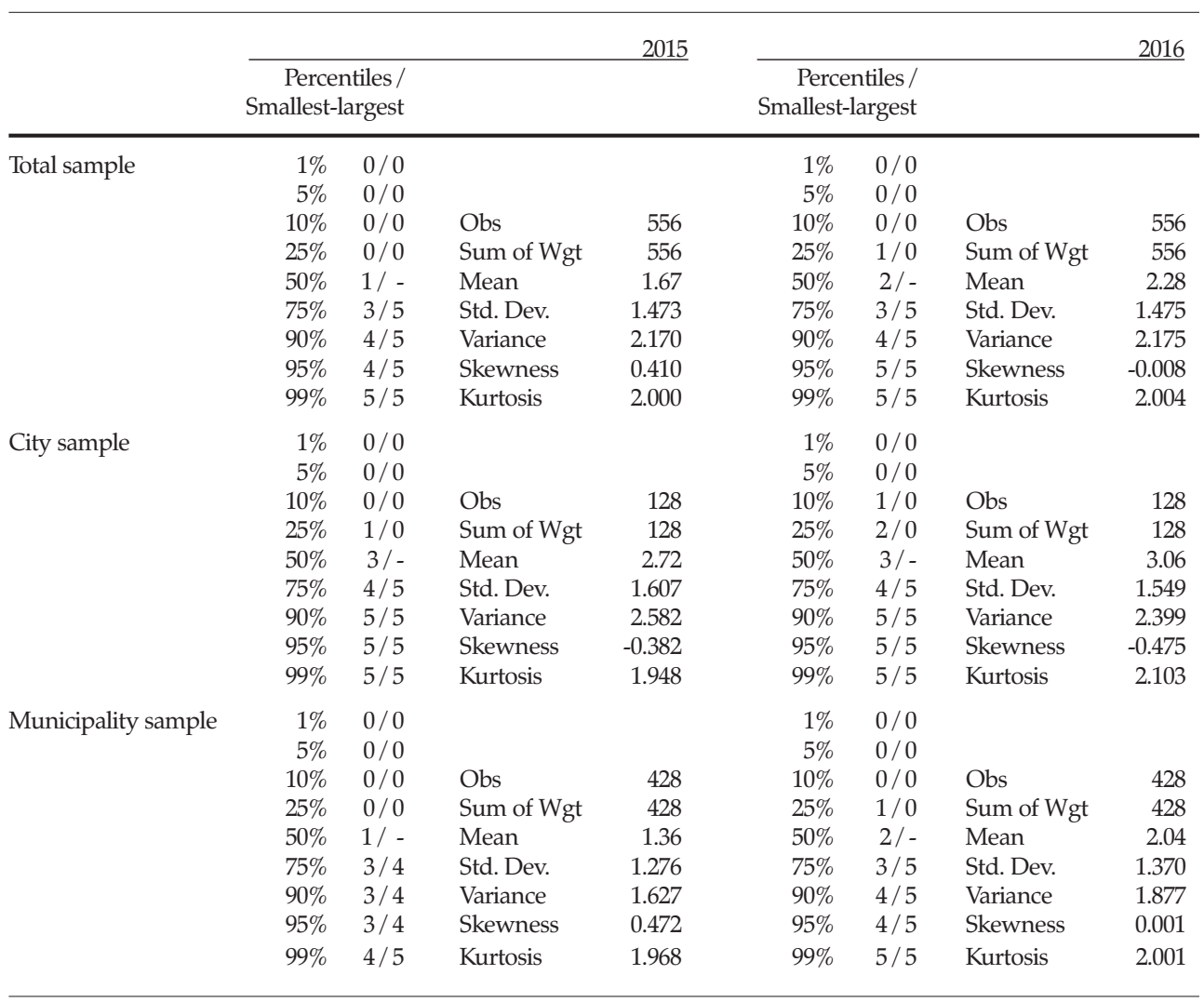

The analysis was conducted on the 2015 and 2016 data, separately for each year, as it was not feasible to use a panel model. First, the level of OLBI is uniquely determined for each LG, i.e., it exhibits time-invariant characteristics. Inter-annual variability with panel data would mean that a fixed-effect model is the best option, but because there were no elections in these two years, all the political variables together with the data for the level of education of mayor/municipality head would be lost. Thus, the optimal strategy was to use regression analysis separately for each year to determine whether the same results are obtained. 
DRUŠ. ISTRAŽ. ZAGREB GOD. 27 (2018), BR. 4, STR. 629-647

OTT, K., MAČKIĆ, V., BRONIĆ, M.: BUDGET...
Based on a literature review and the researchers' own assumptions, a number of economic, political and socio-cultural variables were collected, some of which were used for testing the hypotheses and others as control variables. Although only the variables that were statistically significant were singled out in the model (Table 2), this did not influence the size of the final sample or the findings in the paper. The final variables used in the empirical part of the paper are:

Economic variables

- logarithm of average residents' income p.c. (ln_income p.c.)

- logarithm of total LG expenditures p.c. (ln tc lc $_{\text {p.c.). }}$.

Political variables

- ideological stance of the incumbent (ideo_r - the ruling party in LG is the right-wing Croatian Democratic Union (HDZ) or a coalition in which HDZ participates),

- political competition I - incumbent faced more than one competitor in elections (NoCand_2013) and

- political competition II - incumbent was backed by more than one party (Coal_2013).

Socio-cultural variables

- low level of education of the mayor/municipality head, indicating only a secondary school diploma $\left(e d u_{-} l\right)$ and

- logarithm of LG's population ( $\left.l n \_p o p\right)$.

Based on the correlation matrix, a number of variables did not show statistically significant effects and were not used, although these results are available upon request. The analysis was conducted on the total 'population' (cities and municipalities) and then separately for municipalities and cities. Table 4 presents the descriptive statistics for all the independent variables used in all three samples.

The estimated model comprises two economic (ln income p.c. and $l_{-}$tc_p.c.), three political (ideo_r, NoCand_2013 and Coal_2013) and two socio-cultural variables (ln_pop and $e d u \_l$ ).

A Poisson regression equation with robust standard errors was estimated for each sample, which is represented by the following equation:

$O L B I_{\mathrm{t}}=a_{0}+\beta_{1}$ ln_pop $+\beta_{2}$ ln_income_p.c. $+\beta_{3}$ ln_tc_p.c. +

$\beta_{4}$ ideo $_{\mathrm{r}}+\beta_{5} \mathrm{NoCand}_{2013}+\beta_{6} \mathrm{Coal}_{2013}+\beta_{7} \mathrm{Edu}=1,2$,

where $\alpha_{0}$ indicates a constant, and $\beta_{i}, i=1,2 \ldots 7$ indicates the estimated coefficients of the independent variables. The economic independent variables have a one-year lag, i.e., the OLBI in 2015 is explained by the 2014 logarithm of residents' average income p.c. (OLBI is calculated in the first quarter of the year, i.e., it is determined by events in the previous year much more than events in the current year). All political variables and the level of education of the mayor/municipality head are derived from the local elections held in 2013. 


\begin{tabular}{|c|c|c|c|c|c|c|c|c|c|c|c|}
\hline \multirow{2}{*}{\multicolumn{2}{|c|}{$\begin{array}{l}\text { (1) TABLE } 4 \\
\text { Independent variables } \\
\text { - summary statistics }\end{array}$}} & \multicolumn{9}{|c|}{2015} & \multirow{2}{*}{$\frac{2016}{\operatorname{Max}}$} \\
\hline & & Obs & Mean & Std. Dev. & Min & $\operatorname{Max}$ & Obs & Mean & Std. Dev. & Min & \\
\hline \multirow[t]{7}{*}{ Total sample } & $\ln$ pop & 556 & 8.15 & 0.976 & 5.476 & 13.580 & 556 & 8.15 & 0.976 & 5.476 & 13.580 \\
\hline & ln_income_p.c. & 556 & 10.03 & 0.289 & 9.069 & 10.880 & 556 & 10.06 & 0.267 & 9.108 & 10.679 \\
\hline & $\ln t c \_$tc. & 556 & 7.88 & 0.652 & 6.430 & 9.884 & 556 & 7.94 & 0.613 & 6.508 & 10.016 \\
\hline & ideo_r & 556 & 0.54 & 0.499 & 0 & 1 & 556 & 0.54 & 0.499 & 0 & 1 \\
\hline & NoC̄and_2013 & 556 & 3.54 & 1.457 & 1 & 11 & 556 & 3.54 & 1.457 & 1 & 11 \\
\hline & Coal_2013 & 556 & 0.46 & 0.499 & 0 & 1 & 556 & 0.46 & 0.499 & 0 & 1 \\
\hline & $e d u \_\bar{l}$ & 556 & 0.40 & 0.490 & 0 & 1 & 556 & 0.40 & 0.490 & 0 & 1 \\
\hline \multirow[t]{7}{*}{ City sample } & $\ln \_$pop & 128 & 9.35 & 0.958 & 7.330 & 13.580 & 128 & 9.35 & 0.958 & 7.330 & 13.580 \\
\hline & ln_income_p.c. & 128 & 10.24 & 0.204 & 9.788 & 10.880 & 128 & 10.24 & 0.182 & 9.816 & 10.679 \\
\hline & $\ln t c \_$p.c. & 128 & 8.15 & 0.525 & 7.099 & 9.328 & 128 & 8.14 & 0.504 & 7.067 & 9.349 \\
\hline & $i d \bar{e}=\vec{r}$ & 128 & 0.48 & 0.501 & 0 & 1 & 128 & 0.48 & 0.501 & 0 & 1 \\
\hline & NoC̄and_2013 & 128 & 4.43 & 1.581 & 2 & 11 & 128 & 4.43 & 1.581 & 2 & 11 \\
\hline & Coal_20̄̄3 & 128 & 0.70 & 0.459 & 0 & 1 & 128 & 0.70 & 0.459 & 0 & 1 \\
\hline & $e d u \_\bar{l}$ & 128 & 0.18 & 0.385 & 0 & 1 & 128 & 0.18 & 0.385 & 0 & 1 \\
\hline \multirow{7}{*}{$\begin{array}{l}\text { Municipality } \\
\text { sample }\end{array}$} & ln_pop & 428 & 7.79 & 0.635 & 5.476 & 9.578 & 428 & 7.79 & 0.635 & 5.48 & 9.578 \\
\hline & ln_income_p.c. & 428 & 9.97 & 0.282 & 9.069 & 10.802 & 428 & 10.00 & 0.264 & 9.108 & 10.632 \\
\hline & ln_tc_p.c. & 428 & 7.80 & 0.665 & 6.430 & 9.884 & 428 & 7.89 & 0.611 & 6.861 & 9.988 \\
\hline & ideo $\vec{r}$ & 428 & 0.56 & 0.497 & 0 & 1 & 428 & 0.56 & 0.497 & 0 & 1 \\
\hline & NoC̄and_2013 & 428 & 3.27 & 1.306 & 1 & 9 & 428 & 3.27 & 1.306 & 1 & 9 \\
\hline & Coal_20̄̄3 & 428 & 0.39 & 0.488 & 0 & 1 & 428 & 0.39 & 0.488 & 0 & 1 \\
\hline & $e d u \_\bar{l}$ & 428 & 0.47 & 0.450 & 0 & 1 & 428 & 0.47 & 0.450 & 0 & 1 \\
\hline
\end{tabular}

\section{EMPIRICAL RESULTS}

The results are presented in Table $5 .^{2}$ The results for the total sample (cities+municipalities) confirm all four hypotheses.

(1) TABLE 5

Poisson regression with robust standard error estimates for 2015 and 2016
Each variable has a significant and expected effect: positive for In_income_p.c., In_pop and Coal_2013 and negative for ideo_r. Because the obtained results are confirmed for both years, one can state that they are valid for both years.

\begin{tabular}{|c|c|c|c|c|c|c|c|}
\hline & & \multicolumn{2}{|c|}{ Total sample } & \multicolumn{2}{|c|}{ City sample } & \multicolumn{2}{|c|}{ Municipality sample } \\
\hline & & 2015 & 2016 & 2015 & 2016 & 2015 & 2016 \\
\hline \multirow[t]{8}{*}{ OLBI } & ln_pop & $\begin{array}{l}0.191 \\
(0.042)^{* * *}\end{array}$ & $\begin{array}{l}0.164 \\
(0.033)^{* * *}\end{array}$ & $\begin{array}{c}0.049 \\
(0.055)\end{array}$ & $\begin{array}{c}0.091 \\
(0.052)^{*}\end{array}$ & $\begin{array}{c}0.090 \\
(0.086)\end{array}$ & $\begin{array}{l}0.167 \\
(0.061)^{* * *}\end{array}$ \\
\hline & In_income_p.c. & $\begin{array}{l}0.412 \\
(0.189)^{* *}\end{array}$ & $\begin{array}{c}0.259 \\
(0.137)^{*}\end{array}$ & $\begin{array}{l}1.291 \\
(0.327)^{* * *}\end{array}$ & $\begin{array}{l}1.331 \\
(0.353)^{* * *}\end{array}$ & $\begin{array}{c}0.203 \\
(0.211)\end{array}$ & $\begin{array}{c}0.121 \\
(0.144)\end{array}$ \\
\hline & $\ln t_{-}$_ $p . c$. & $\begin{array}{c}0.102 \\
(0.070)\end{array}$ & $\begin{array}{c}0.095 \\
(0.051)^{*}\end{array}$ & $\begin{array}{l}-0.003 \\
(0.105)\end{array}$ & $\begin{array}{c}0.001 \\
(0.101)\end{array}$ & $\begin{array}{c}0.059 \\
(0.087)\end{array}$ & $\begin{array}{c}0.089 \\
(0.060)\end{array}$ \\
\hline & ideo_r & $\begin{array}{l}-0.122 \\
(0.070)^{*}\end{array}$ & $\begin{array}{l}-0.120 \\
(0.053)^{* *}\end{array}$ & $\begin{array}{c}0.033 \\
(0.096)\end{array}$ & $\begin{array}{l}-0.000 \\
(0.083)\end{array}$ & $\begin{array}{l}-0.174 \\
(0.091)^{*}\end{array}$ & $\begin{array}{l}-0.137 \\
(0.065)^{* *}\end{array}$ \\
\hline & NoCand_2013 & $\begin{array}{c}0.010 \\
(0.026)\end{array}$ & $\begin{array}{l}-0.016 \\
(0.021)\end{array}$ & $\begin{array}{c}0.023 \\
(0.032)\end{array}$ & $\begin{array}{l}-0.015 \\
(0.031)\end{array}$ & $\begin{array}{c}0.019 \\
(0.036)\end{array}$ & $\begin{array}{l}-0.010 \\
(0.027)\end{array}$ \\
\hline & Coal_2013 & $\begin{array}{c}0.123 \\
(0.072)^{*}\end{array}$ & $\begin{array}{l}0.144 \\
(0.053)^{* * *}\end{array}$ & $\begin{array}{c}0.081 \\
(0.115)\end{array}$ & $\begin{array}{c}0.128 \\
(0.089)\end{array}$ & $\begin{array}{c}0.070 \\
(0.094)\end{array}$ & $\begin{array}{l}0.129 \\
(0.065)^{* *}\end{array}$ \\
\hline & $e d u \_l$ & $\begin{array}{l}-0.090 \\
(0.078)\end{array}$ & $\begin{array}{c}-0.032 \\
(0.056)\end{array}$ & $\begin{array}{l}-0.023 \\
(0.131)\end{array}$ & $\begin{array}{c}0.071 \\
(0.100)\end{array}$ & $\begin{array}{l}-0.095 \\
(0.093)\end{array}$ & $\begin{array}{l}-0.062 \\
(0.064)\end{array}$ \\
\hline & _cons & $\begin{array}{l}-6.034 \\
(1.507)^{* * *}\end{array}$ & $\begin{array}{l}-3.837 \\
(1.120)^{* * *}\end{array}$ & $\begin{array}{l}-12.875 \\
(2.759)^{* * *}\end{array}$ & $\begin{array}{l}-13.448 \\
(3.040)^{* * *}\end{array}$ & $\begin{array}{l}-2.824 \\
(1.841)\end{array}$ & $\begin{array}{l}-2.424 \\
(1.328)^{*}\end{array}$ \\
\hline $\mathrm{N}$ & & 554 & 554 & 128 & 128 & 426 & 426 \\
\hline
\end{tabular}

${ }^{*} p<0.1 ;{ }^{* *} p<0.05 ;{ }^{* *} p<0.01$ 
DRUŠ. ISTRAŽ. ZAGREB GOD. 27 (2018), BR. 4, STR. 629-647

OTT, K., MAČKIĆ, V., BRONIĆ, M.: BUDGET...
Principal-agent theory provides a theoretical rationale for the positive effect of the ln_income_p.c. It is in the incumbents' interest to disclose the budget and show citizens how successfully they are managing their funds, if they want to stay in office (Alcaide Muñoz et al., 2017; Ferejohn, 1999).

The positive impact of the $\ln \_$pop variable is supported by the neo-institutional theory. Higher number of inhabitants results in greater external pressures on the LG that leads to socially acceptable BT practices.

Legitimacy and principal-agent theory, which argue that greater political competition is an incentive for the incumbent to perform well, are confirmed by the positive effect of Coal 2013 on the OLBI.

In line with Ferejohn's model, left-wing governments defending larger budgets have incentives to choose above zero transparency, and thus the negative effect of ideo $r$ on the OLBI is expected. Furthermore, an increase in total expenditures p.c. as suggested by Ferejohn's model leads to higher OLBI scores in 2016.

The variable $e d u \_l$ has a negative sign, but it is not statistically significant. The negative relationship between incumbents' having a secondary school diploma and the OLBI is expected because a secondary school diploma is the lowest possible level of an incumbent's education. This is in line with Tavares \& Ferreira da Cruz (2014), who also found a positive relationship between incumbents' education levels and transparency scores.

Comparing the results for 2015 and 2016, for the total sample, the strength and order of the variables are unchanged. This applies equally for the economic, political and level of education of the mayor/municipality head variables. For both 2015 (0.412) and 2016 (0.259), residents' ln income_p.c. is the most important determinant of the OLBI. A positive correlation between residents' income and BT has also been found by Serrano-Cinca et al. (2009) and Styles and Tennyson (2007), and on the national level by Ingram (1984).

Ln pop has the second highest impact on the OLBI in 2015 (0.191) and in 2016 (0.164), thus confirming the majority of other authors' findings (e.g., Alcaide Muñoz et al., 2017; Gallego-Álvarez, Rodríguez-Domínguez, \& García-Sánchez, 2010; García \& García, 2008; Guillamón et al., 2011; Serrano-Cinca et al., 2009; Sol, 2013; Styles \& Tennyson, 2007).

Positive effect for the variable Coal_2013 indicates that a coalition candidate has on average a positive effect $(0.123)$ on the OLBI, which is also confirmed in $2016(0.144)$. This positive effect was also found by García and García (2008), Araujo and Tejedo-Romero (2016) and Esteller-Moré and Otero (2012).

If the incumbent is a right-wing politician (ideo $r$ ), the OLBI, on average, decreases by 0.122 in 2015 and by 0.120 in 2016.3 
DRUŠ. ISTRAŽ. ZAGREB GOD. 27 (2018), BR. 4

OTT, K., MAČKIĆ, V., BRONIĆ, M.: BUDGET... STR. 629-647

This result is consistent with the findings of the effect of partisanship on the local-level BT (e.g., Araujo \& Tejedo-Romero, 2016; Caamaño-Alegre et al., 2013; Guillamón et al., 2011; Sol, 2013).

Thus, all four hypotheses have been confirmed for the total sample, but they could be only partially accepted on the city and municipality levels. Analysing the samples at the level of cities and municipalities, the first conclusion was rather straightforward and expected. According to Ferejohn's model, one would expect that due to the wealth effect in the city sample, residents' income p.c. would have a positive impact on the OLBI. Since this effect is confirmed for the total sample, it must originate from either the city or municipality level. Following the same logic, since the importance of the political variables was confirmed for the total sample and they did not show statistically significant effects for the city sample, it is reasonable to expect them to originate within the municipality sample. This is also in line with the theoretical predictions of Ferejohn's model due to lower rents and ideological stance of the incumbent.

The estimated models for cities indicate that the only significant variable was ln_income_p.c. (1.291 in 2015 and 1.331 in 2016) and additionally in 2016, $\ln$ pop (0.091). These results have also been found by Serrano-Cinca et al. (2009) and Styles and Tennyson (2007).

The last sample comprises 428 municipalities, and the results for 2015 suggest that the only statistically significant effect comes from the variable ideo $r(-0.174)$. For 2016, political (ideo $r$ with -0.137 and Coal $201 \overline{3}$ with 0.129 ) and socio-cultural variables (ln_pop with 0.167 ) have a statistically significant effect. It seems that on this level, BT is a question of political will to distinguish oneself from the competition, and as Sol (2013) argues, left-wing LGs are more sensitive to the provision of transparency than right-wing LGs. For both years, a negative effect is found for a right-wing incumbent, thus confirming that the political effect captured for the total sample is actually driven by the municipalities and that the main driving force at this level is the incumbents' ideological stance. If the incumbent is a member of the right-wing Croatian party (HDZ) or a coalition in which the HDZ participates, the OLBI is on average lower.

\section{CONCLUSIONS}

This study contributes to the growing body of literature on LG BT determinants. Clear and robust evidence indicates that average p.c. residents' income is the most important determinant of the OLBI at the level of the total sample, followed by population, political competition and the incumbent's ideology.

Average p.c. residents' income is the most important driver at the level of cities, whereas at the municipality level, ide- 
DRUŠ. ISTRAŽ. ZAGREB GOD. 27 (2018), BR. 4, STR. 629-647

OTT, K., MAČKIĆ, V., BRONIĆ, M.: BUDGET... ology matters. Principal-agent theory provides a theoretical rationale for the positive effect of average p.c. residents' income on the OLBI; the incumbents are willing to publish budget documents in order to stay in power in better-off cities. The neo-institutional theory is confirmed through the positive effect of population in all samples. As residents' income p.c. and population may act as a proxy for the institutional capacity of an LG in the total and city samples (i.e., the combination of the administrative and fiscal capacity of LGs), the results point to the necessity of reconsidering having numerous small LGs since they might lack the institutional capacity to address basic issues (such as maintaining adequate websites and publishing budget documents online).

At the municipality level, greater political competition results in higher BT and the voluntary demonstration of incumbents' efficient management, which falls under legitimacy and the principal-agent theory. In low administrative and fiscal capacity surroundings, BT becomes more of a question of political will, and a left-wing LG might be more sensitive to the provision of BT.

As it is necessary to motivate citizens to demand and LGs to offer more BT, it seems that the IPF's ratings of LGs acted as an incentive for many incumbents to increase their BT due to political competition among them.

For the time being, the lack of data and the short time span of study prevented the use of a more sophisticated econometric method. Future research might use random or fixed (given the possible political and socio-economic data) effects panel data models; examine the effect of the debt, access to Internet, etc., or try to identify a proxy for institutional capacity.

\section{ACKNOWLEDGEMENTS}

We thank all the team members and consultants on the Understanding, monitoring and analysing local government budget transparency: Case study of Croatia and Slovenia - Open local budget index (OLBI) project. We also thank Francisco Veiga, Linda Veiga and Josip Glaurdić for their comments and suggestions.

\section{FUNDING}

This work was supported by the Croatian Science Foundation [grant IP-2014-09-3008].

\section{NOTES}

1 Since there are municipalities with OLBI equal to zero, a negative binomial distribution is also used (Poisson-gamma mixture addressing the overdispersion of data, e.g., more zeros and more high values than a Poisson distribution predicts). The same results were obtained and are available upon request.

2 The pseudo R2 varies between 0.05 and 0.06 . 
DRUŠ. ISTRAŽ. ZAGREB GOD. 27 (2018), BR. 4 STR. 629-647

OTT, K., MAČKIĆ, V., BRONIC, M.:

BUDGET..

\section{REFERENCES}

${ }^{3}$ Interaction variables were created by multiplying the economic variable ( $\ln \_t c \_$.c.) by the incumbent's ideological stance. The obtained results for $\ln \_t c \_r \_$.. . also confirm that an increase in total expenditures when the party/coalition in power is the HDZ results in a decrease in the OLBI in 2015 and in 2016. Results are available upon request.

Act on the Right of Access to Information (2013). Official Gazette, 25/2013, 85/2015.

Alcaide Muñoz, L., Rodríguez Bolívar, M. P., \& López Hernández, A. M. (2017). Transparency in governments: A meta-analytic review of incentives for digital versus hard-copy public financial disclosures. American Review of Public Administration, 47(5), 550-573. https://doi. org/10.1177/0275074016629008

Alt, J. E. (2002). The comparative political economy: Credibility, accountability, and institutions. In I. Katznelson \& H. Milner (Eds.), Political science: The state of the discipline (pp. 147-171). New York: Norton.

Alt, J. E., \& Lowry, R. C. (2010). Transparency and accountability: Empirical results for US States. Journal of Theoretical Politics, 22(4), 379-406. https://doi.org/10.1177/0951629810375641

Araujo, J. F. F. E., \& Tejedo-Romero, F. (2015). Determinants of local governments' transparency in times of crisis: Evidence from municipality-level panel data. Administration \& Society, 50(4), 527-554. https://doi. org/10.1177/0095399715607288

Araujo, J. F. F. E., \& Tejedo-Romero, F. (2016). Local government transparency index: Determinants of municipalities' rankings. International Journal of Public Sector Management, 29(4), 327-347. https://doi.org/10. 1108/IJPSM-11-2015-0199

Benito, B., \& Bastida, F. (2009). Budget transparency, fiscal performance, and political turnout: An international approach. Public Administration Review, 69(3), 403-417. https://doi.org/10.1111/j.1540-6210. 2009.01988.x

Besley, T. (2006). Principled agents? The political economy of good government. New York: Oxford University Press.

Budget Act (2012). Official Gazette, 87/2008, 136/2012, 15/2015.

Caamaño-Alegre, J., Lago-Peñas, S., Reyes-Santias, F., \& Santiago-Boubeta, A. (2013). Budget transparency in local governments: An empirical analysis. Local Government Studies, 39(2), 182-207. https://doi. org/10.1080/03003930.2012.693075

Committee in Charge of Monitoring the Conflict of Interest (2016). Register of state officials. Committee in charge of monitoring the conflict of interest. Available at https://www.sukobinteresa.hr/hr/registar-duznosnika Croatian Bureau of Statistics (CBS) (2016). Census 2011. MS Excel tables. Zagreb: Bureau of Statistics.

Cullis, J., \& Jones, P. (1997). Public finance and public choice. New York: Oxford University Press Inc. 
DRUŠ. ISTRAŽ. ZAGREB GOD. 27 (2018), BR. 4, STR. 629-647

OTT, K., MAČKIĆ, V. BRONIĆ, M.: BUDGET...
Debreceny, R., Gray, G. L., \& Rahman, A. (2002). The determinants of internet financial reporting. Journal of Accounting and Public Policy, 21(4-5), 371-394. https://doi.org/10.1016/S0278-4254(02)00067-4

Deegan, C. (2002). Introduction. Accounting, Auditing and Accountability Journal, 15(3), 282-311. https://doi.org/10.1108/09513570210435852

DiMaggio, P. J., \& Powell, W. W. (1991). Introduction. In P. J. DiMaggio \& W. Powell (Eds.), The new institutionalism and organizational analysis (pp. 1-38). Chicago: University of Chicago Press.

Esteller-Moré, A., \& Polo Otero, J. P. (2012). Fiscal transparency. Public Management Review, 14(8), 1153-1173. https://doi.org/10.1080/147 19037.2012.657839

Ferejohn, J. (1999). Accountability and authority: Towards a theory of political accountability. In A. Przeworski, S. Stokes, \& B. Manin (Eds.), Democracy, accountability, and representation. Cambridge studies in the theory of democracy (pp. 131-153). Cambridge: Cambridge University Press. https://doi.org/10.1017/CBO9781139175104.005

Gallego-Álvarez, I., Rodríguez-Domínguez, L., \& García-Sánchez, I.-M. (2010). Are determining factors of municipal E-government common to a worldwide municipal view? An intra-country comparison. Government Information Quarterly, 27(4), 423-430. https://doi.org/10.1016/j.giq. 2009.12.011

Gandía, J. L., \& Archidona, M. C. (2008). Determinants of web site information by Spanish city councils. Online Information Review, 32(1), 35-57. https://doi.org/10.1108/14684520810865976

García, A. C., \& García, J. G. (2008). Determinantes de la divulgación de información contable a través de Internet por parte de los gobiernos locales [Determinants of Internet financial disclosure by local governments]. Spanish Journal of Finance and Accounting, 37(137), 63-84. https://doi.org/10.1080/02102412.2008.10779639

García-Tabuyo, M., Sáez-Martin, A., \& Caba-Pérez, M. D. C. (2016). Mandatory versus voluntary disclosures. Drivers of proactive information provision by local governments in Central America. Information Development, 32(4), 1199-1215. https://doi.org/10.1177/0266666 915595260

Giroux, G., \& McLelland, A. J. (2003). Governance structures and accounting at large municipalities. Journal of Accounting and Public Policy, 22(3), 203-230. https://doi.org/10.1016/S0278-4254(03)00020-6

Guillamón, M.-D., Bastida, F., \& Benito, B. (2011). The determinants of local government's financial transparency. Local Government Studies, 37(4), 391-406. https://doi.org/10.1080/03003930.2011.588704

Hameed, F. (2005). Fiscal transparency and economic outcomes. IMF Working Paper, (05/225). Available at https://www.imf.org/external/pubs/ft/ wp/2005/wp05225.pdf

Ingram, R. W. (1984). Economic incentives and the choice of state government accounting practices. Journal of Accounting Research, 22(1), 126-144. https://doi.org/10.2307/2490704

Jensen, M. C., \& Meckling, W. H. (1976). Theory of the firm: Managerial behavior, agency costs and ownership structure. Journal of Financial Economics, 3(4), 305-360. https://doi.org/10.1016/0304-405X(76)90026-X 
DRUŠ. ISTRAŽ. ZAGREB GOD. 27 (2018), BR. 4 STR. $629-647$

OTT, K., MAČKIĆ, V., BRONIĆ, M.: BUDGET...
Khagram, S., Fung, A., \& de Renzio, P. (2013). Open budgets: The political economy of transparency, participation, and accountability. Washington, DC: Brookings Institution Press.

Kopits, G., \& Craig, J. (1998). Transparency in government operations. IMF Occasional Paper, (158). https://doi.org/10.5089/9781557756978.084

Laswad, F., Fisher, R., \& Oyelere, P. (2005). Determinants of voluntary Internet financial reporting by local government authorities. Journal of Accounting and Public Policy, 24(2), 101-121. https://doi.org/ 10.1016/j.jaccpubpol.2004.12.006

Lowi, T. J. (1972). Four systems of policy, politics, and choice. Public Administration Review, 32(4), 298-310. https://doi.org/10.2307/974990

Ma, L., \& Wu, J. (2011). What drives fiscal transparency? Evidence from provincial governments in China (April 12, 2011). 1st Global Conference on Transparency Research, Rutgers University-Newark, May 19-20, 2011. https://doi.org/10.2139/ssrn.1807767

Mačkić, V. (2014). Political budget cycles at the municipal level in Croatia. Financial Theory and Practice, 38(1), 1-35. https://doi.org/10.3326/ fintp.38.1.1

McLean, I. (1997). Uvod u javni izbor [Public choice: An introduction]. Zagreb: Fakultet političkih znanosti.

Ministry of Finance (2016). Lokalni proračuni. Lokalni proračuni-Arhiva [Local budgets. Local budgets - Archive]. Zagreb: Ministry of Finance.

Ministry of Regional Development and EU Funds (2016). Access to information. Zagreb: Ministry of Regional Development and European Union Funds.

Open Government Partnership (OGP) (2012). Croatia action plan 2012-2013. Open Government partnership. Available at http://www.open govpartnership.org/sites/default/files/legacy_files/country_action_plans/ Croatia-OGP-Action\%20plan_0.pdf

Ott, K., \& Bronić, M. (2015). Public participation in fiscal policy and budget processes in Croatia: GIFT Report. Available at http://www.fiscal transparency.net/wp-content/themes/enfold/includes/gift_embedded/ en/resource_open.php?IdToOpen $=20150706114$

Ott, K., Bronić, M., \& Petrušić, M. (2015). Budget transparency in Croatian counties, cities and municipalities (November 2014-March 2015). Newsletter - an occasional publication of the Institute of Public Finance, (97), 1-13. https://doi.org/10.3326/nle.2015.97

Ott, K., Bronić, M., Petrušić, M., \& Stanić, B. (2016). Budget transparency of Croatian counties, cities and municipalities (November 2015 - March 2016). Newsletter - an occasional publication of the Institute of Public Finance, (107), 1-14. https://doi.org/10.3326/nle.2016.107

Patten, D. M. (1992). Intra-industry environmental disclosures in response to the Alaskan oil spill: A note on legitimacy theory. Accounting, Organizations and Society, 17(5), 471-475. https://doi.org/10.1016/ 0361-3682(92)90042-Q

Pérez, C., Bolívar, M. P. R., \& Hernández, A. M. L. (2014). The determinants of government financial reports online. Transylvanian Review of Administrative Sciences, (10), 5-31. 
DRUŠ. ISTRAŽ. ZAGREB GOD. 27 (2018), BR. 4, STR. 629-647

OTT, K., MAČKIĆ, V., BRONIĆ, M.: BUDGET...
Piotrowski, S. J., \& van Ryzin, G. G. (2007). Citizen attitudes toward transparency in local government. The American Review of Public Administration, 37(3), 306-323. https://doi.org/10.1177/0275074006296777

Rodríguez Bolívar, M. P., Alcaide Muñoz, L., \& López Hernández, A. M. (2013). Determinants of financial transparency in government. International Public Management Journal, 16(4), 557-602. https://doi.org/ 10.1080/10967494.2013.849169

Roemer, J. E. (2001). Political competition: Theory and applications. London: Harvard University Press.

Serrano-Cinca, C., Rueda-Tomás, M., \& Portillo-Tarragona, P. (2009). Factors influencing e-disclosure in local public administrations. Environment and Planning C: Politics and Space, 27(2), 355-378. https://doi.org/ $10.1068 / \mathrm{c} 07116 \mathrm{r}$

Sol, D. A. (2013). The institutional, economic and social determinants of local government transparency. Journal of Economic Policy Reform, 16(1), 90-107. https://doi.org/10.1080/17487870.2012.759422

State Electoral Commission (2016). Elections and referendums. State Electoral Commission. Available at http://www.izbori.hr/ws/index.html? documentId =8BD9243DD4840AD3C1257C5C004BF6B3

Styles, A. K., \& Tennyson, M. (2007). The accessibility of financial reporting of U.S. municipalities and the internet. Journal of Public Budgeting, Accounting and Financial Management, 19(1), 56-92. https://doi. org/10.1108/JPBAFM-19-01-2007-B003

Tavares, A., \& Ferreira da Cruz, N. (2014). The determinants of local government transparency: A preliminary analysis. In Proceedings of the 8th International Conference on Theory and Practice of Electronic Governance (ICEGOV '14) (pp. 117-123). New York, NY: ACM. https://doi. org/10.1145/2691195.2691291

Vuković, V. (2017). The political economy of local government in Croatia: Winning coalitions, corruption, and taxes. Public Sector Economics, 41(4), 387-420. https://doi.org/10.3326/pse.41.4.1

\section{Proračunska transparentnost lokalnih vlasti: politička ekonomija proračuna gradova i općina u Hrvatskoi}

Katarina OTT

Institut za javne financije, Zagreb

Velibor MAČKIĆ

Ekonomski fakultet, Zagreb

Mihaela BRONIĆ

Institut za javne financije, Zagreb

Rad istražuje transparentnost proračuna hrvatskih lokalnih jedinica, odnosno odnos između indeksa otvorenosti lokalnih proračuna (OLBI) te ekonomskih, političkih i sociokulturnih varijabli. Primjenom regresijske analize utemeljene na Poissonovoj distribuciji, na jedinstvenoj bazi podataka svih 
DRUŠ. ISTRAŽ. ZAGREB GOD. 27 (2018), BR. 4 STR. 629-647

OTT, K., MAČKIĆ, V., BRONIĆ, M.:

BUDGET.. razlike među uzorcima i godinama te utvrđuje značenje različitih varijabli za različite uzorke. U ukupnom uzorku (općine i gradovi) i na razini gradova najvažnija je odrednica OLBI-ja prosječni dohodak po stanovniku, čime se potvrđuje Ferejohnov model principala i agenta. Na razini općina najvažnije su političke varijable (ideologija i politička konkurencija), što je u skladu s teorijom principala i agenta te teorijom legitimnosti. Rezultati istraživanja pokazuju da je nužno preispitivanje broja lokalnih jedinica, posebice onih manjih, koje ne mogu održavati minimalne standarde proračunske transparentnosti, uz istodobno motiviranje građana da zahtijevaju i lokalnih jedinica da nude više proračunske transparentnosti.

Ključne riječi: proračunska transparentnost, lokalne vlasti, Hrvatska, politička ekonomija

\section{(c) (1) (\$)}

Međunarodna licenca / International License:

Imenovanje-Nekomercijalno / Attribution-NonCommercial 